\title{
Acara Indonesia Lawyer Club (ILC) di TVOne dalam Perspektif Public Sphere
}

\author{
Ageng Kurniawan ${ }^{1^{*}}$ \\ ${ }^{1}$ Magister Ilmu Komunikasi Universitas Jenderal Soedirman \\ J1. Prof. Dr. Boenyamin No.708, Purwokerto 53122 - Indonesia \\ *Email Korespondensi: agengku12@gmail.com
}

\begin{abstract}
Abstrak
Tayangan talkshow Indonesia Lawyers Club (ILC) di TV One sejauh ini diminati khalayak, sehingga selalu ditunggu pemirsa televisi, bahkan sampai memiliki penonton loyal. Tema ILC menjadi bahan obrolan menarik di masyarakat. Keunikan dalam setiap segmen di ILC adalah, siapa pun boleh berbicara apa pun terkait dengan isu terkini tentang masalah sosial, hukum dan politik, sesuatu yang dulu relatif tabu dan tidak bisa diakses oleh khalayak. Acara itu juga "didengar" pemerintah dan pihak terkait yang permasalahannya menjadi tema diskusi, sehingga ini seperti memperagakan konsep public sphere yang disodorkan Habermas. Penelitian ini menggunakan teknik studi kepustakaan, wawancara dengan pemirsa tayangan ILC dan pengamatan langsung dengan melihat acara tersebut di televisi. Kesimpulan penelitian: acara ILC memiliki kekuatan intrinsik berupa kualitas program, pengakuan dalam bentuk penghargaan dan pencapaian rating tinggi. Tayangan tersebut mampu mewujudkan hubungan saling menguntungkan antara TVOne dengan pengamat sosial, politikus, lawyer, dan masyarakat umum.
\end{abstract}

Kata kunci: ILC, Masalah sosial, Hukum, Politik, Public sphere

\section{PENDAHULUAN}

Pada awalnya Indonesia Lawyers Club merupakan program talkshow lokal dengan nama Jakarta Lawyers Club. Namun seiring permintaan dari pemirsa agar agar materi diskusi lebih bersifat nasional, nama acara ini akhirnya disesuaikan. Acara ini menampilkan diskusi publik membahas permasalahan sosial, hukum dan politik yang sedang jadi perhatian publik. Pembawa acara diskusi ini dipandu wartawan senior sekaligus pemimpin redaksi TV One, Karni Ilyas.

Acara ILC tayang secara live setiap hari Selasa pukul 19:30 - 22:30 WIB, dan di siarkan kembali atau tayangan ulang pada hari Minggu pukul 19.00 - 22.00 WIB. Indonesia Lawyers Club adalah sebuah program Talkshow yang dikemas secara interaktif untuk memberikan pembelajaran hukum bagi para pemirsa. Sejauh ini, acara itu diminati khalayak sehingga ditunggu-tunggu pemirsaTVone, bahkan sampai memiliki penonton loyal.

Komisi Penyiaran Indonesia (KPI) memilih tujuh acara bincang-bincang yang paling banyak ditonton berdasarkan hasil survei (KPI) bekerja sama dengan Ikatan Sarjana Komunikasi Indonesia (ISKI). ILC TV One berada di urutan keempat dengan 52,10 persen setelah Program Kick Andy Metro TV (68,90 \%), Hitam Putih Trans7 sebanyak 67,30 \%, dan Mata Najwa Metro TV (60,90\%). Namun ketiga program selain ILC tersebut, formatnya tidak menyuguhkan diskusi terbuka seperti di ILC.

Realitas ini menimbulkan pertanyaan apa sebenarnya kekuatan ILC dan bagaimana mereka menghadirkan para aktor politik, publik figur, para pengamat dan akademisi untuk berpartisipasi aktif dan berdiskusi sehingga memungkinkan konsep public sphere ala Habermas jadi kenyataan. Konsep itu seperti disimulasikan di layar kaca dengan berbicara kritis, mengajukan bukti-bukti dan juga pembelaan, bahkan sampai dengan memvonis secara implisit siapa yang bersalah.

Daya tarik program talkshow terletak pada topik pembicaraan atau permasalahan yang di bicarakan (Wibowo, 2009: 83). Di ILC, seolah menjadi pengadilan yang ideal. Asumsi awal tentu saja tidak lepas dari euforia politik, ketika siapa pun boleh berbicara apa pun yang terkait dengan isu terkini tentang masalah sosial, hukum dan politik bangsa, suatu hal yang dulunya relatif tabu atau tak bisa diakses oleh khalayak. Kesemuanya itu seperti menawarkan keadilan dan harapan baru seperti 
konsep public sphere yang disodorkan Habermas. Terbukti, acara itu didengar pemerintah dan pihak terkait yang permasalahannya menjadi tema diskusi.

Hal ini selaras dengan Public Sphere dalam pengertian politik yang berarti menyediakan sebuah ruang - berupa wacana, lembaga-lembaga, suatu ruang topografik - di mana orang dalam perannya sebagai warga memiliki akses masuk di dalam sebuah dialog kemasyarakatan yang sedang mempersoalkan sesuatu demi kepentingan umum. Ruang yang demikian itu, dengan kondisi komunikasi tertentu yang mewarnainya, menjadi sesuatu hal penting dalam demokrasi ( Dahglren, Peter 2002). Oleh karena itu, tujuan penilitian ini adalah mebahas acara talkshow ILC dalam perspektif public sphere.

\section{TINJAUAN PUSTAKA}

Habermas adalah pemikir sosial yang identik konsep Public Sphere. Menurut Habermas, Public Sphere dikonsepsionalisasikan sebagai suatu realitas kehidupan sosial di mana terdapat suatu proses pertukaran informasi dan berbagai pandangan berkenaan dengan pokok persoalan yang tengah menjadi perhatian umum sehingga dalam proses tadi terciptalah pendapat umum (Dahglren, Peter, 2002). Dengan dihasilkannya pendapat umum maka pada gilirannya akan membentuk kebijakan negara dan pada akhirnya akan membentuk suatu tatanan masyarakat secara keseluruhan.

Hal ini sejalan dengan pikiran Lazarsfeld (1944) yang mengemukakan konsep two step communication, bahwa suatu pesan politik seringkali harus melewati kelompok kecil yang berpengaruh (leader opinion). Lewat merekalah efek yang semula direncanakan dapat terwujud. Kunci penting dalam konsep Public Sphere adalah keaktifan dari warga masyarakat memanfaatkan hak-haknya untuk ikut berpikir dalam wacana tertentu, khususnya yang berkaitan dengan permasalahan sosial-politik.

Pemikiran Habermas itu bisa dipahami setidaknya dalam dua perspektif. Pertama, Habermas mencoba menggambarkan munculnya ruang publik di kalangan calon kaum borjuis dalam spirit kapitalisme liberal di Abad 18. Kategori Public Sphere semacam ini dapat ditemui dalam realitas sejarah masyarakat barat khususnya di Inggris, Perancis dan Jerman. Pada masa sebelum itu, bisa dikatakan tidak ada ruang sosial yang layak disebut public sebagai lawan dari private.

Dengan semakin berkembangnya konsep negara kebangsaan, lembaga perwakilan, perekonomian, dan lahirnya media cetak, maka mulai berkembang akar kemunculan Public Sphere di Eropa Barat. Dalam Public Sphere ini terdapat kelompok sosial tertentu atas dasar pendidikan, kelas kepemilikan (biasanya pada kalangan pria) dan berproses melalui berbagai media seperti jurnal, pamflet, leaflet dan surat kabar termasuk di dalam lingkungan tertentu seperti bar, coffee house dan berbagai klub. Pertukaran informasi aktual, yang berlangsung terus menerus dalam sebuah diskusi yang seringkali dihangatkan dengan perdebatan merupakan gejala baru yang menurut Habermas amatlah berarti.

Kedua, konsep Public Sphere memasuki warna baru dengan mulai memudarnya kelompok borjuis dalam konteks masyarakat industri yang makin maju dan munculnya demokrasi massa. Dengan adanya demokrasi massa, publik yang semula diwakili oleh kalangan elite terpelajar terbatas mulai dimasuki oleh masyarakat kebanyakan yang tidak begitu berpendidikan. Sementara negara, dalam kepentingannya untuk mengendalikan pertentangan kapital menjadi makin intervensionis. Batas antara wilayah public dan private, baik dalam pengertian ekonomi politik maupun budaya makin tipis. Organisasi besar dan kelompok kepentingan menjadi partner politik kunci bagi negara, menghasilkan bentuk politik feodal baru yang makin menggantikan peran-peran yang semula dilakoni masyarakat.

Berkembangnya karakteristik kepemilikan media massa, khususnya ketika kekuatan komersial mengubah fungsi komunikasi publik menjadi public relation dan makin menguatnya periklanan dan hiburan, maka fungsi kritis media massa makin terkikis. Publik lalu terkotak-kotak sedemikian rupa, sehingga kehilangan daya ikatnya. Habermas ingin membuat maksud yang lebih eksplisit dari aturan normatif yang ideal dan dapat menggambarkan bagaimana ruang publik tersebut dapat berkontribusi sebagai kerangka yang esensial dalam masyarakat demokratis (Midgley, 2012:34). 
Public Sphere dalam pengertian politik berarti menyediakan sebuah ruang - berupa wacana, lembaga-lembaga, suatu ruang topografik di mana orang dalam perannya sebagai warga memiliki akses masuk di dalam sebuah dialog kemasyarakatan yang sedang mempersoalkan sesuatu demi kepentingan umum, atau dengan kata lain akses menuju dunia politik dalam pengertian yang luas. Ruang yang demikian ini, dengan kondisi komunikasi tertentu yang mewarnainya, menjadi sesuatu hal yang penting dalam demokrasi. Fungsi Public Sphere dengan demikian adalah memenuhi persyaratan komunikasi tertentu sabagai variabel terbentuknya demokrasi. Akan tetapi, Habermas melihat bahwa pada periode tersebut ruang publik hanya dikuasai oleh kelompok-kelompok borjuis. Dengan kata lain, tidak seluruh elemen warga negara memiliki suara yang setara. Dalam artian, tidak ada ekualitas pada warga negara. Untuk itulah kemudian Habermas merasa perlu untuk membuat konsep ruang publik yang lebih ideal untuk menciptakan kesetaraan ini.

Dengan praktek ruang publik borjuis pada masa itu, menempatkanya dalam posisi rumit. Hal ini dikarenakan ruang publik justru memainkan peranan sentral dalam masyarakat yang semakin demokratis dan pembentukan opini percakapan mengenai isu publik yang diproduksi dan menopang publik" (Dahglren, 2000).

Pemikiran intelektual Habermas berakar dari mazhab Frankfurt dan tesisnya mengenai Public Sphere menjadi inspirasi bagi riset media kritis. Akan tetap, dasar pemahaman Habermas tentang demokrasi dan public sphere tidaklah murni dikendalikan oleh tradisi liberal Anglo-American dengan ide dasarnya tentang market place of ideas. Dalam diskursus liberal (yang klasik dan bukan neoliberal) media dan demokrasi, biasanya tidak menggunakan istilah Public Sphere (Dahglren, 2000).

Faktor-faktor dalam dimensi struktur sosial di antaranya berkaitan dengan ekologi politik dari media, menyusun batas-batas dari institusi media dan profil organisasi demikian juga sifat-sifat dari informasi dan bentuk-bentuk representasi yang memungkinkan diartikulasikan. Dimensi struktur sosial ini tentu saja akan berdampak pada pola interaksi sosiokultural. Dengan demikian struktur sosial secara kompleks membentuk seperangkat kondisi bagi Public Sphere yang bisa juga diisi oleh ketiga dimensi yang lainnya (McQuail, 2002: 195-209).

Dimensi struktur sosial tentu saja menjadi dimensi yang paling sulit diraih sehingga bagi sebagian kalangan ahli dimensi ini diabaikan saja jika tidak ingin kehilangan fokus soal Public Sphere. Kisah memudarnya Public Sphere merupakan isu yang hangat hingga kini, tentu saja dengan modifikasi versi oleh kalangan pemerhati dan peneliti. Bahkan kemudian ada yang mempertanyakan akan manfaat konsep Public Sphere. Meski demikian konsep ini tetap sesuatu yang berharga guna memahami proses sosial di mana media massa menjadi salah satu kekuatan dalam konstelasi kekuatan-kekuatan yang menentukan dalam masyarakat.

Satu hal yang patut dicatat dalam telaah mengenai Public Sphere ini adalah, dalam masyarakat yang cenderung lemah demokrasinya dan struktur masyarakatnya sangat tidak egaliter tidak akan memberi kesempatan bagi terciptanya Public Sphere.

Gagasan Habermas di atas memang bisa dibilang sebuah cita-cita ideal dalam konteks historis masa itu yang kalau kita bandingkan dengan konteks zaman sekarang tentunya prosesnya tidak sesederhana itu. Dalam perkembangan masyarakat yang makin besar maka proses terbentuknya wacana menuju opini publik tadi lalu dijembatani oleh media massa salah satunya adalah televisi.

Mengimplematsikan fungsi jurnalisme televisi secara teknis perlu menyesuaikan diri dengan karakter medianya (Blum, 1984). Dari sini sudah terformat kaidah kerja, yaitu menjadian fakta sosial sebagai tontonan. Karenanya secara sederhana jurnalisme televisi sering disebut sebagai upaya memungut fakta sosial yang dapat "ditulis" dengan kamera dan menulis narasi kata untuk telinga. "Menulis" dengan kamera dan menulis untuk telinga tentulah memerlukan disiplin dan metode kerja yang khas (Hilliard, 1991). Menulis dengan kamera memerlukan pemberian detail dari fakta sosial yang didapat disajikan secara visual. Tradisi sinematografi merupakan pangkal bagi aspek jurnalisme televisi ini. Sementara menulis dengan telinga, merupakan tradisi dari radio (Cohler, 1994).

Media dengan logikanya semakin diadopsi dan menjadi bagian dari kehidupan institusi dan aktor politik walaupun aktivitas politik tetap relatif otonom dari media. Livingstone (2008) bahkan secara provokatif menulis, bahwa tidak ada bagian dari dunia, tidak ada aktivitas manusia, yang tidak tersentuh oleh media. Tersentuh bukanlah dominasi total, namun harus dibaca sebagai bagian dari 
p-ISSN: 0853-4470 - Vol. 02, No. 01 (2019), pp. 27-33

proses internalisasi logika media. Logika media berangkat dari tiga fungsi dasar mediasi, yang pertama adalah fungsi penyebaran atau penyiaran yang berasal dari kapasitas teknologi media yang melipat ruang dan waktu. Kedua, fungsi semiotik di mana media mengkodekan dan memformat pesan yang sesuai dengan bagaimana manusia mempersepsi dan memproses informasi. Ketiga adalah fungsi ekonomis, ketika media menjadi industri dengan standar produksi massal yang melahirkan hitunghitungan rating. Tiga fungsi dasar mediasi inilah yang membentuk logika media yang menjadi penting dalam menjelaskan mediatisasi.

Terdapat beberapa konsekuensi dari proses mediatisasi politik terutama jika kita melihat di Indonesia. Pemimpin partai atau kandidat dalam pemilihan diseleksi oleh institusi politik dengan memperhatikan kemampuan dalam menangani media, keahlian dalam melakukan spin isu politik, dan citra di dalam media. Menjadi media darling adalah keinginan untuk mencapai karier politik. Alihalih menggarap aliansi dengan kekuatan politik lain dan bermain isu atau ideologi, praktik politik hari ini tak lagi berpusat pada ideologi. Media menjadi tempat pertempuran baru. Konsekuensinya, perbincangan politik di media tidak lagi berujung pada deliberasi atau mencari titik temu, atau paling tidak, irisan berbagai kepentingan politik. Logika tontonan sinetron nampaknya menjadi logika utama perbincangan politik: dramatisasi diolah ketimbang kedalaman substansi, menguras emosi dipilih ketimbang beradu argumen rasional, mencari kambing hitam diutamakan ketimbang solusi.

\section{METODE PENELITIAN}

Penelitian ini menggunakan pendekatan kualitatif dengan teknik pengumpulan data melalui studi kepustakaan yaitu teknik pengumpulan data dengan mengadakan studi penelaahan terhadap buku-buku, literatur, catatan, dan laporan-laporan yang ada hubungannya dengan masalah yang dipecahkan (Nazir, 1988: 111). Selain studi kepustakaan untuk lebih melengkapi serta lebih memahami konteks dan suasana diskusi, dilakukan pengamatan, menonton tiga episode tayangan ILC pada 8 Januari 2019 dengan tema Menguji Netralitas KPU, 15 Januari 2019 dengan tema Penegakan Hukum di Mata 01 dan 02, serta 22 Januari 2019 dengan tema Babak Pertama Debat Capres 2019: Siapa yang Menang?

Triangulasi Data dilakukan dengan membandingkan data yang sama, namun diperoleh dari sumber berbeda untuk menangkap realitas yang valid, yaitu yang dihasilkan dari studi kepustakaan, pengamatan dengan menyaksikan ILC dan wawancara terhadap empat orang informan yang suka menyaksikan acara ILC.

\section{HASIL PENELITIAN}

Dari hasil pengamatan menonton tiga episode tayangan IL sangat terasa bagaimana acara tersebut memberikan bahan diskusi tentang apa yang terjadi di negeri ini. Ketiga episode tersebut mampu memaparkan dengan lugas apa yang terjadi di layar kaca tentang isu-isu politik secara aktual terutama di lingkup pemerintahan pusat, terutama menjelang pemilihan umum seperti saat ini. Informasi tersebut merupakan kebutuhan yang memang merupakan fungsi dari media massa untuk menyajikannya. Hal ini juga senada dengan keterangan dari keempat informan yang pada intinya menyebutkan bahwa dari ILC mereka mendapatkan informasi yang lebih berimbang mengenai isuisu yang terjadi dewasa ini.

Logika media berangkat dari tiga fungsi dasar mediasi, pertama, fungsi penyebaran atau penyiaran yang berasal dari kapasitas teknologi media yang melipat ruang dan waktu. Kedua, fungsi semiotik di mana media mengkodekan dan memformat pesan yang sesuai dengan bagaimana manusia mempersepsi dan memproses informasi. Ketiga adalah fungsi ekonomis, ketika media menjadi industri dengan standar produksi massal yang melahirkan rating. Tiga fungsi dasar mediasi inilah yang membentuk logika media yang menjadi ramuan lengkap ILC sehingga mampu bertahan sejauh ini.

Pembawa acara, Karni Ilyas, dengan lugas menerangkan kekuatan retorika sebagai pembawa. "Strategi retorika Karni Ilyas yang memukau dengan teknik persuasi melalui Indonesia Lawyers Club (ILC) berhasil menarik perhatian masyarakat melalui penggunaan strategi retorika verbal dan nonverbal, teknik persuasi, pemilihan jenis diksi, denotatif, konotatif, publik, ilmiah, dapat diakses, 
dan gaya bahasa yang digunakan memiliki strategi yang dapat mempengaruhi audien". Informan AM berkomentar: "Sosok Karni Ilyas yang berbicara saja terbata-bata sangat ditaati dan dihormati saat diskusi di ILC berlangsung".

Informan IS mengatakan: "Saya heran dengan alur diskusi yang dirancang oleh Karni Ilyas, menurut saya seperti tanpa konsep, mengalir begitu saja namun bisa memikat pemirsa untuk terus nonton ILC sampai usai".

Media dalam hal ini ILC bukan sekedar menjadi ajang diskusi namun berubah menjadi tempat pertempuran baru. Konsekuensinya, perbincangan politik di media tidak lagi berujung pada sebuah kesepakatan atau mencari titik temu, atau paling tidak, mendapatkan irisan yang sama dalam berbagai kepentingan politik namun logikanya bisa seperti tontonan sinetron dimana logika utama perbincangan politik didramatisasi dan diolah ketimbang kedalaman substansi, lebih menguras emosi kerap dipilih ketimbang beradu argumen rasional, mencari kambing hitam diutamakan ketimbang mencari solusi.

Terdapat beberapa konsekuensi dari proses mediatisasi politik terutama jika kita melihat di Indonesia. Pertama, pemimpin partai atau kandidat dalam pemilihan diseleksi oleh institusi politik dengan memperhatikan kemampuan dalam menangani media, keahlian dalam melakukan spin isu politik, dan citra di dalam media. Menjadi media darling adalah tiket untuk sampai di puncak karier politik. Pencitraan adalah model politik yang dimediatisasi. Alih-alih menggarap aliansi dengan kekuatan politik lain dan bermain isu atau ideologi, praktik politik hari ini tak lagi berpusat pada ideologi. Dalam diskusinya, aktor-aktor politik mempertaruhkan kemampuan spinning isu mereka: mengaburkan fokus pembicaraan, beradu sindiran dan ejekan halus, dan tak jarang melontarkan ancaman yang kasar dan melecehkan.

Informan AM mengatakan: "Tidak ada kawan sejati, yang ada ialah kepentingan sejati, sehingga orang yang berkecimpung dalam dunia politik harus selalu memperhatikan setiap isu yang berkembang. ILC merupakan salah satu 'literatur' yang mesti diikuti'. Sang pembawa acara, Karni Ilyas, pun paham betul bagaimana sepenuhnya mengeksploitasi kekuasaannya, bisa dengan cara mengatur ritme dan memprovokasi komentar-komentar, atau bahkan dalam momen tertentu, tidak segan segan Karni Ilyas terkesan seperti menyepelekan argumentasi peserta dengan alasan tidak relevan atau dengan kata kata "bukan giliran anda berbicara".

Informan FL mengatakan: "Karni Ilyas sangat pintar memainkan tempo, memancing komentar miring dan lihai mencari kata penutup tiap segmen yang membuat penasaran pemirsa". ILC di lain sisi, memungkinkan khalayak untuk berpartisipasi dalam konsumsi informasi politik. Tanpa ILC, kasus-kasus korupsi, konflik politik, dan urusan penguasa dan pejabat di Jakarta mungkin tak terakses dan hal ini tidak bisa kita temui di era Orde Baru. Jawaban bahwa media membutuhkan politik akan menjadi kebenaran yang hampir pasti, mengingat posisi media yang subordinat dari sistem dan kekuasaan politik. Punya kedekatan dan hubungan baik dengan penguasa adalah modal dasar untuk bertahan hidup dan lolos dari ancaman bredel. Media menjadi lebih dominan daripada politik. Media tidak harus meliput kegiatan pejabat, misalnya, jika liputan tersebut tidak bisa dikonversi menjadi iklan.

Habermas telah menyodorkan konsep tentang Public Sphere sebagai suatu realitas kehidupan sosial di dalam mana terdapat suatu proses pertukaran informasi dan berbagai pandangan berkenaan dengan pokok persoalan yang tengah menjadi perhatian umum sehingga dalam proses tadi terciptalah pendapat umum. Dengan dihasilkannya pendapat umum maka pada gilirannya akan membentuk kebijakan negara dan pada akhirnya akan membentuk suatu tatanan masyarakat secara keseluruhan. Hasil wawancara dengan kelima informan menyatakan keselarasan dengan hal tersebut, bahwa mereka merasa ada pengalaman baru atau setidaknya ada perasaan bahwa pemikiran mereka disuarakan oleh narasumber.

Kunci penting dalam konsep Public Sphere adalah keaktifan dari warga masyarakat memanfaatkan hak-haknya untuk ikut berpikir terlibat di dalam suatu wacana yang sedang hangat pada hari suatu saat tertentu, khususnya yang berkaitan dengan permasalahan politik. Dalam perkembangan masyarakat yang makin besar maka proses terbentuknya wacana menuju opini publik tadi lalu diantarai oleh media massa salah satunya adalah televisi. 
p-ISSN: 0853-4470 - Vol. 02, No. 01 (2019), pp. 27-33

Dari hasil pengamatan dalam tiga tayangan ILC terlihat bagaimana semua peserta diskusi sangat aktif, bahkan kadang agresif dengan memotong pembicaraan orang jika substansinya menyudutkan pendapatnya. Para narasumber yang hadir benar benar memaksimalkan waktu yang diberikan untuk menyampaikan pendapatnya. Bahkan jika peserta atau narasumber tidak bisa hadir secara langsung mereka akan mengikuti dan memberikan komentar melalui sambungan telepon atau video call, mereka seperti tidak ingin hak bicara atau berpendapatnya berlalu begitu saja.

Gagasan Habermas di atas memang bisa dibilang sebuah cita-cita ideal dalam konteks historis masa itu yang kalau dibandingkan dengan konteks zaman sekarang tentunya prosesnya tidak sesederhana itu. Sebuah kejadian unik yang ditulis di http://wartakota.tribunnews.com edisi 28 Agustus 2018 menyebutkan: "diskusi mingguan Indonesia Lawyers Club (ILC) yang selalu disiarkan lewat saluran televisi TVOne mendadak tidak tayang hari ini, Selasa (28/8/2018)". Berbagai pertanyaan muncul akibat pembatalan tayang secara mendadak itu.

Rocky Gerung pun angkat bicara terkait hal tersebut. Hal itu terlihat dalam akun medsos Rocky Gerung yang menulis judul 'ILC Batal Tayang Karena Kendala TEKNIS (Tekanan Istana). Mohon Maaf atas kedunguannya. Terima Kasih. Di pihak lain Fadli Zon menimpali, lewat akun twitternya dengan menulis 'Singkatan baru dr kata "Teknis" Tekanan Istana. Kreatif n mengena'. Ini merespon akun Instagram @ ILC_tvOnenews., "Kepada pemirsa setia ILC, mohon maaf dikarenakan adanya kendala teknis, kami sampaikan bahwa hari ini, 28 Agustus 2018, untuk sementara \#ILCTidakTayangLive. Sampai bertemu di ILC yang akan datang. Sebagai pengganti, malam ini Pkl 20.00 WIB kami tayangkan kembali > \#ILCPerangSocmed. Selamat menyaksikan".

Bagaimana sebuah penundaan acara televisi yang kemudian ditanggapi 'lain' oleh narasumber langganan ILC tersebut tentu menyiratkan makna pentingnya tema-tema yang diangkat sehingga menarik perhatian berbagai pihak. Persoalanya kemudian adalah, apakah memang acara ILC ini juga turut 'mengintervensi' kebijakan pemerintah? Dari hasil wawancara juga diketahui bagaimana pengaruh ILC dalam beberapa kasus di masa lalu, yang mereka sebutkan antara lain: "Cicak Versus Buaya, Sudden Death: KPK VS Polri, impor daging “Bunda Putri Bunda yang Tertukar dan Proyek Pulau Reklamasi, Tak Terbendung?" yang semuanya menurut mereka mempengaruhi sikap pemerintah.

Dalam kaidah pertelevisian, apa artinya program bagus tapi tidak ditonton. Dikutip dari CNN Indonesia, industri televisi publik Indonesia umumnya mengacu pada data rating yang dikeluarkan oleh AC Nielsen. Rating itu adalah jumlah penonton suatu siaran atau program di bagi populasi televisi. Kemudian share adalah jumlah penonton suatu program dibagi jumlah orang yang pada saat itu sedang menonton TV. Kalau rating, pembaginya total seluruh penonton sedangkan share hanya orang yang sedang menonton saja. Rating dipakai ketika membandingkan program yang tayang pagi, siang dan malam karena pembaginya konstan jadi apple to apple sedangkan share digunakan pada saat yang sama misalnya mau membandingkan peforma suatu siaran dengan stasiun kompetitor di jam yang sama.

Komisi Penyiaran Indonesia (KPI) memilih tujuh acara bincang-bincang yang paling banyak ditonton berdasarkan hasil survei Komisi Penyiaran Indonesia (KPI), yang bekerja sama dengan Ikatan Sarjana Komunikasi Indonesia (ISKI) dan sejumlah perguruan tinggi terkemuka. Indonesia Lawyer's Club TV One mampu meraih 52,10 persen dan menempatkan pada urutan keempat, sedangkan diatasnya ada Program Kick Andy Metro TV berada pada urutan teratas dengan penonton sebanyak 68,90 persen, disusul dengan Mata Najwa Metro TV dengan angka 60,90 persen dan Hitam Putih Trans7 dengan perolehan 67,30 persen.

Namun dalam ketiga program di yang memperoleh rating atas ILC kesemuanya tidak menyuguhkan diskusi terbuka dan setara seperti di ILC. Hal ini sejalan dengan standar yang ditetapkan KPI sebagai program berkualitas dari panel ahli. Program ILC juga memperoleh nilai tinggi di indikator keberagaman $(3,22)$, pengawasan $(3,5)$, meningkatkan daya kritis $(3,24)$ dan kepentingan masyarakat/publik $(3,09)$.

\section{KESIMPULAN}


p-ISSN: 0853-4470 - Vol. 02, No. 01 (2019), pp. 27-33

Acara Talk show Indonesia Lawyers Club memiliki kekuatan intrinsik berupa kualitas program, pengakuan dalam bentuk penghargaan dan pencapaian rating yang tinggi, hal ini menunjukan bahwa tayangan tersebut mampu mewujudkan hubungan yang saling menguntungkan diantara TV one selaku media, pengamat sosial, politikus, lawyer, dan masyarakat umum. Dengan pemilihan materi berupa permasalahan sosial, hukum dan politik yang sedang menjadi perhatian publik, tayangan ini mampu menggiring opini pemirsanya yang pada gilirannya diharapkan akan dapat membentuk pengetahuan, interes dan sikap baru dari khalayak.

\section{Daftar Pustaka}

Baran, Stanley J. (2012). Pengantar Komunikasi Massa Melek Media dan Budaya. Jakarta: Erlangga. Benne. (1980). Cultural Studies: Studi dan praktik. Kreasi wacana: Yogyakarta

Dahglren, Peter. (2002). The Public Sphere as Historical Narrative dalam McQuail's Reader in Mass Communication Theory, London: Sage

https://www.cnnindonesia.com/hiburan/20170922131852-220-243328/mengulik-nielsenperusahaan-penghitung-rating-televisi diakses Februari 2019 jam 10.50

https://www.viva.co.id/berita/nasional/948926-riset-kpi-ilc-raih-indeks-tertinggi-program-talkshow diakses 10 Februari jam 21.15

https://www.viva.co.id/berita/nasional/1102212-survei-kpi-sebut-kualitas-program-siaran-televisiindonesia-menurun10 Februari 2019 jam 10.40

http://wartakota.tribunnews.com edisi 28 Agustus 2018 “diskusi mingguan Indonesia Lawyers Club (ILC) yang selalu disiarkan lewat saluran televisi tvOne mendadak tidak tayang hari ini, Selasa (28/8/2018)". Di akses 20 Januari 2019 jam 10.00

http://jsi.web.id/2018/01/7-acara-talk-show-paling-banyak-ditonton-versi-survei-kpi， diakses 10 Februari 2019 jam 10.30

http://www.remotivi.or.id/amatan/156/Indonesia-Lawyers-Club:-Kolonisasi-Logika-Televisidalam-Logika-Politik diakses 20 Januari 2019 jam 10.30

(http://jsi.web.id/2018/01/7-acara-talk-show-paling-banyak-ditonton-versi-survei-kpi)

Nurudin. Pengantar Komunikasi Massa. Jakarta: PT Raja Grafindo Persada.

Tester, Keith. (2003). Media Budaya dan Moralitas. Yogyakarta: Juxtapose dan Kreasi Wacana. 